\title{
HOUSING AS AN EXPRESSION OF SELF-IDENTITY IN CONTEMPORARY ALGERIA: THE WORK OF EL-MINIAWY BROTHERS
}

\author{
Tahar Bellal
}

\author{
Departement d'architecture, Faculte des sciences de \\ l'ingenieur, Universite Ferhat Abbas, Setif, Algeria \\ e-mail: bellal56@yahoo.fr
}

\begin{abstract}
This paper tries to shed light on post-traditional environment in Algeria in a post global civilisation era. Some chosen projects implemented in some parts of the country are dealt with in relation to the expression of self identity through housing architecture. The focus of the work is on methods, achievements and implications of the projects. As from the seventies of the last century Algeria witnessed dramatic changes in its physical environment. The cities became the focus of international construction activities and many internationally renowned architects competed for large scale projects (Oscar Niemeyer, Ricardo Boffil, Kenzo Tang, etc). The projects chosen in this paper all deal with housing and include a housing scheme in Maadher near Msila, the second example in El Oued, the third is a housing project in Ouled Djellal. All of these projects by El Miniawy brothers disciples of the late Hassan Fathy, address critical aspects of the built environment. Yet one can consider these projects as representative of architectural thinking and activity in the country. This working paper reveals general aspects to gain comprehensive understanding, rather than statistical knowledge of Algerian built environment.
\end{abstract}

Keywords: Modern techniques, local traditions, identity, housing

\begin{abstract}
Abstrak
Tulisan ini mencoba untuk menjelaskan tentang lingkungan pasca-tradisional di Aljazair pada era pascaperadaban global. Beberapa projek terpilih yang diimplementasikan di beberapa wilayah di Aljazair berhubungan dengan ekspresi identitas diri melalui arsitektur pemukiman. Fokus penelitian ini adalah pada metode, prestasi dan implikasi dari projek-projek tersebut. Sejak tahun tujuh puluhan abad yang lalu, Aljazair menyaksikan perubahan dramatis dalam lingkungan fisiknya. Kota-kota menjadi fokus kegiatan pembangunan internasional dan banyak arsitek internasional berkompetisi untuk projek-projek berskala besar (Oscar Niemeyer, Ricardo Boffil, Kenzo Tang, dan lain-lain). Seluruh projek yang dipilih dalam makalah ini berhubungan dengan pemukiman, yaitu perumahan di Maadher dekat Msila, di El Oued, dan di Ouled Djellal. Seluruh projek El Miniawy, murid dari almarhum Hassan Fathy, ini mengutamakan aspek kritis di lingkungan binaan. Walaupun demikian, kita dapat menganggap projek-projek ini sebagai perwakilan pemikiran dan aktivitas arsitektural di negara ini. Paper ini mengungkapkan aspek-aspek umum untuk memperoleh pemahaman yang komprehensif, daripada sekedar pengetahuan statistika lingkungan bangunan Aljazair.
\end{abstract}

Kata kunci: Tradisi lokal, teknik modern, pemukiman, identitas

\section{Introduction}

"The constraints of the environment made sobriety [qanaa] and frugality [kafaf], the most recommendable virtues. The ideology of development increases needs and the push to satisfy these needs, this is contrary to the life style that is in keeping with the environment."

This paper is an attempt to identify some of the lessons which can be drawn from different housing schemes chosen as case studies. What meaning do they have for present and future Algerian architecture? What are the methods, achievements, and implications? To answer these questions in full is not yet possible, and I shall limit myself to a few observations to initiate further thought and discussion.

The case studies dealt with in this paper imply a strategy in the working of a physical environment and are, perhaps instructive not only as individual cases but as a whole. Yet one can consider these projects as representative of architectural thinking and activity. As opposed to the traditional built environment which is:

"An end product of an interaction between constant elements such as the Charia -Islamic law-, the climate and variable elements such as economic and industrial means, that is to say a product of a societal process."

The new built environment, product of technologies generated elsewhere has meant that modernisation came in as a finished piece, rarely filtered through collective experience within a nation and thus ill adapted to its particular needs. For instance in traditional environments the architecture of the house and that of the mosque has always been an extension of each other, modern buildings broke this link. Today's architecture of the mosque is given a treatment as if it is something of another age. It is 
no use having a mosque that looks as if it was done in the $15^{\text {th }}$ century era and a modern housing scheme that looks as if it comes from today's New York, London, or Paris (Figure 1). The traditional built environment which developed according to a number of civilisation strands among which the long and involved ottoman presence that started in $1516^{3}$, still has valuable lessons for the architects and planners creating new environments, but the prognosis of its survival is uncertain. The physical presence of a vast and varied architectural heritage which has not, for the most part, been integrated into the international language and culture of architecture remains a challenge to all architects building in the country. The heritage is there to accept, to reject, or to engage in a dialogue by understanding its concepts and its idioms, and by building upon $\mathrm{it}^{4}$.

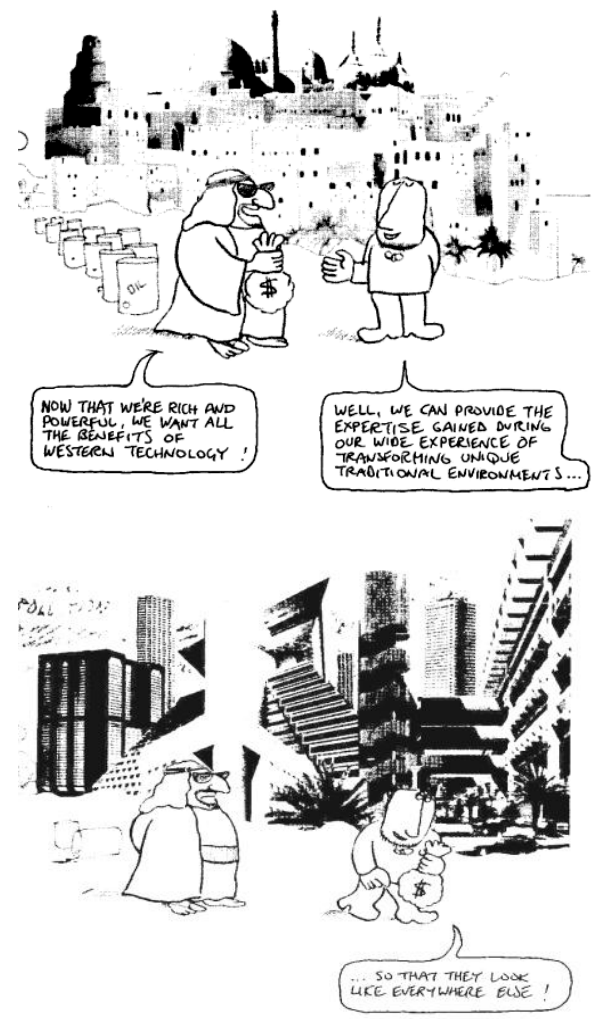

Figure 1. Traditional environments have lost their identity by imposing the international functional style

\section{Theoretical Grounding to the Empirical Exploration}

Since independence Algeria has become aware of the cultural values that are at stake. Architects in particular have realised that they must live with the buildings they create, and have become involved in the sophisticated process of distinguishing the valid elements of their traditions from the anachronisms. They also have a growing personal interest in efforts to reinterpret the standard forms of the international metropolis in the light of particular national backgrounds. With increased experience they have sorted out the four main elements which had for centuries contributed to the peculiarities of traditional architecture and which, they slowly began to realise, might just as logically influence modern design. The elements were climate, local materials and building techniques, habits of living and traditional forms of design.

Climate is a powerful factor. Builders must protect the inhabitants from the sun by limiting windows, providing shade and insuring adequate ventilation. Since modern design usually calls for large windows, architects generally settle on some kind of protective screens or panels outside the windows. Since such devices also enable the designer to introduce playful or striking decorative patterns, yet maintain order and harmony through prefabrication techniques, it has been a happy compromise. Valid architecture will also consider the climate in selecting the fabric of the building itself, in exposing it to, or protecting it from, prevailing winds and blazing afternoon sunshine, and in such features as wall thickness, roof insulation or the height of ceilings.

The second element, the availability of local materials and building techniques, is no longer a restrictive factor in architecture; concrete and steel are totally international materials, basically devoid of regional characteristics. But imaginative architects have achieved some striking effects by searching out and using characteristic materials such as native stone, brick, stucco, ceramic and tiles. By contrasting local materials with modern ones, the architects have also produced some original and valid regional themes.

Specific living habits have much less impact. Functionally modern buildings -office towers, airport terminals and broadcasting stations- will differ little from non-Algerian and Arab, international structures, but in buildings where the personal, human elements are important -"villas" apartment buildings and some schools- particular styles of living can shape a structure. New town planning schemes also reflect basic social habits.

The influence of the fourth element, traditional forms of design, is the easiest to spot. For although both dome and arch are structurally obsolete when executed in reinforced concrete, they do remain a popular element in design. As a matter of fact, the example of the Hussein Dey Islamic centre and college in Algiers by the late Bouchama A. tried to revive local design elements and traditions in contemporary practice in order to preserve continuity and reflect change. Its form is an answer to the brief, is a vast freestanding symmetrical block (Figure 2). 
To create an identity or "local" architectural theme from those few elements would be a considerable challenge for any architect. What it means is that he must consciously integrate essentially Western elements into the local environment. In effect it is trying to mix pride in the distant past with a search for a modern image, and it takes gifted and skillful designers to find a satisfying solution.

Some architects have been successful in creating a regional tone by stressing such traditional aspects as cubic simplicity, solid masses and asymmetrical distribution of openings. The study sample chosen in this paper as worthy of recognition reflects the diversity of needs and resources within the country. All of these projects address critical aspects of the built environment such as the development of an architectural formal language and of building skills.
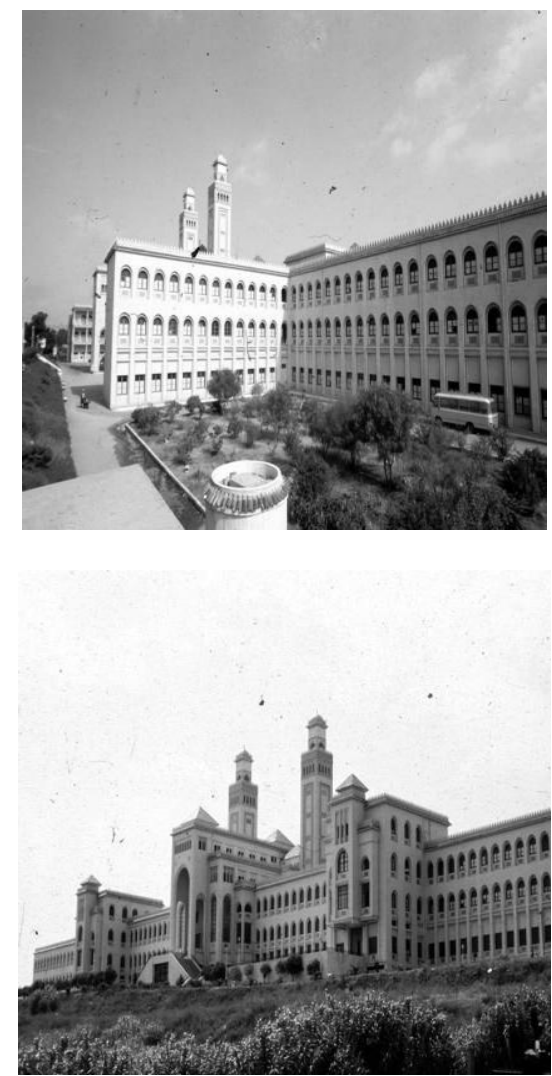

Figure 2. The Hussein Dey Islamic Centre and College in Algiers by the late Bouchama is a try to revive local design elements and traditions in contemporary practice

\section{Case study 1: The Maadher Project}

To begin with, some relevant approaches had been implemented in the Algerian context. The most advanced articulation of an Algerian contemporary architecture can be found in buildings and projects by Hany El Miniawy and Abderahman El Miniawy who partly collaborated with the architect Aly Seradj. The works of these young Arab architects are closely connected to the Islamic past without contradicting present day conditions ${ }^{5}$.

The projects by the El Miniawy reflect the use of local materials and the acceptance of local traditions as the major goals for their design (Figure 3 and 4). But one should mention that the Algerian experience with improved local materials started as early as 1942 when a very rational and impressive regional hospital in Adrar (southern part of the country) using stabilised soil was erected by the Belgian architect Michel Luychx ${ }^{6}$. The El Miniawy project was the experimental village of Maadher near Msila, one of the thousand new villages of the agrarian revolution.

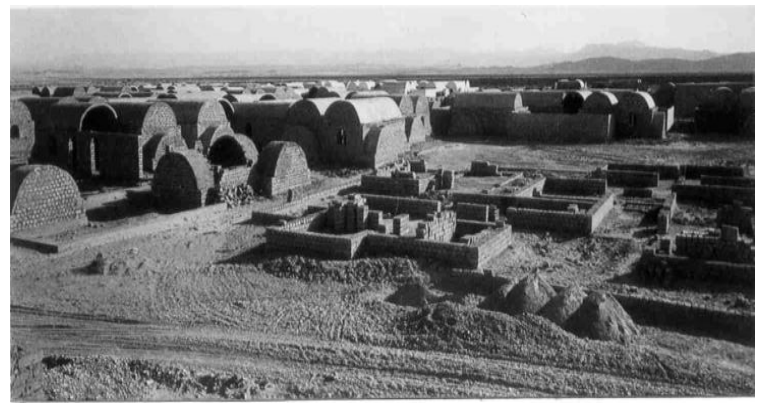

Figure 3. Maadher village under construction, the vaults for roofs. The work of Hassan Fathy has influenced this architecture

\section{Method of approach}

The village is built of mud bricks made on the site and consists of four houses grouped around a shared courtyard each house having in addition its own private courtyard. Since the villagers were nomads, it is difficult to talk about the appropriateness of permanent housing to lifestyle. The housing is certainly appropriate to the local climate and economy, and the cluster of four units around an open space for the women, allows for social interchange ${ }^{7}$. Typical of a production oriented attitude, however, the government as client has divided housing into three categories: urban, semi urban, and rural; so that the programme, which at the beginning did not even include the courtyard, failed to relate satisfactorily to people's needs. It was only after the architects had finished several projects in Algeria such as housing schemes in Sidi Khaled and Ouled Djellal in the southern part of the country, that the government came to appreciate the importance of some of the missing elements and agreed to accept them. 


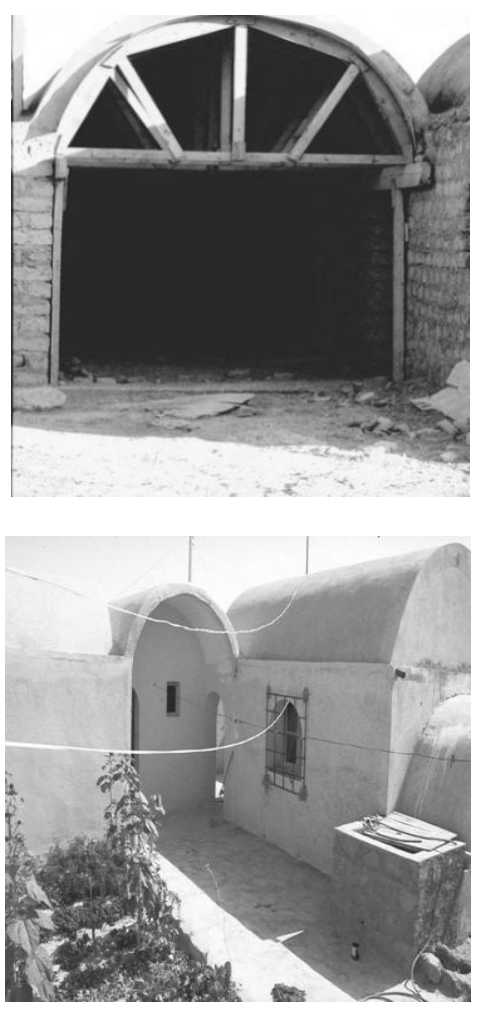

Figure 4. With its simple vaulted forms the project is seen as a research for appropriate building system

\section{Achievements}

El Miniawy's project in Maadher with its simple vaulted forms is seen as a research for appropriate building system, in which a new labour intensive method of construction developed into an architectural language as an achievement. The project responds to the harsh climate, fits the needs of its users and establishes a quietly impressive presence in its flat, semi arid surrounding. It has to be said that the project provides an environment in which people can live, work and practice their spaces harmoniously and to the fullest. It is an image that asserts its local identity in the face of current worldwide trends toward sweeping globalization. This is architecture of and for the people, meeting their needs and concerns locally, providing a setting for health and life.

\section{Implications}

The contemporary use of a traditional building language in a search for a new architectural idiom is identified as an implication. The project also reflected the period of transition in Algerian architecture, marked by the experimentation and the search for environments responsive to human needs. In my opinion, it helped to redefine architecture as it attempted to resolve the most basic and critical issues confronting the poor people of Algeria. On the political side, the project made the policy-makers more involved in the promotion of the locally available materials. The authorities stressed the use of the materials:

"The aim for the construction based on local materials was fixed at 90000 dwellings/year, during the decade 1990-2000, 30\% of these constructions should be built with stabilised soil". ${ }^{8}$

\section{Case study 2: Housing scheme in El Oued}

The public-housing project comprises 400 units in the city of El Oued (Figure 5) also by El Miniawy brothers, located in East-Central Algeria. It is set in a mountainous desert area, characterized by scattered settlements and small villages, and serves a wide variety of middle class families. The project as realized is the result of collaborative efforts between the architects and the local authorities. With the clear aim of being responsive to the culture and environment of the region, the design and construction were developed over a period of more than ten years, based on social studies and surveys and a strong awareness of the regional identity.

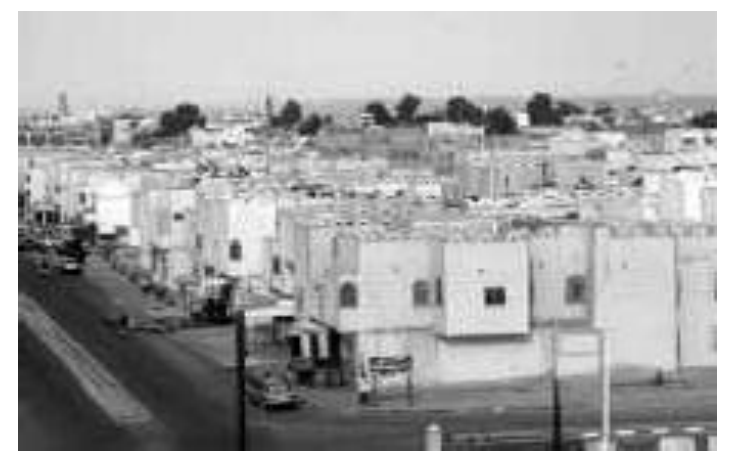

Figure 5. General view of 400 housing units in El Oued

\section{Method of Approach}

The design concept attempted to develop a desert urban fabric in two directions: the first is the social fabric of public spaces including patios, pedestrian pathways, playgrounds, and spaces for women activities. The second is a climatically appropriate fabric with densely shaded areas and diverted ventilation to help combat the summer heat. The design is characterised by arcades and internal spaces (Figure 6). In keeping with local tradition, public and private areas are separated. At a micro level, visitor's areas are in the front of the unit with the rest of the unit on a different level overlooking a central patio. The technology adopted for the project is simply a reinforced concrete construction system. Through sensitivity to the climate and to the cultural traditions of the inhabitants, the reinterpretation of socio-spatial needs into built form for public housing has resulted in a 
residential environment that is both functional and efficient. The incorporation of traditional climatecontrol techniques into the construction system paves the way for developing aesthetic standards for public-housing schemes and results in a visually appealing residential environment.
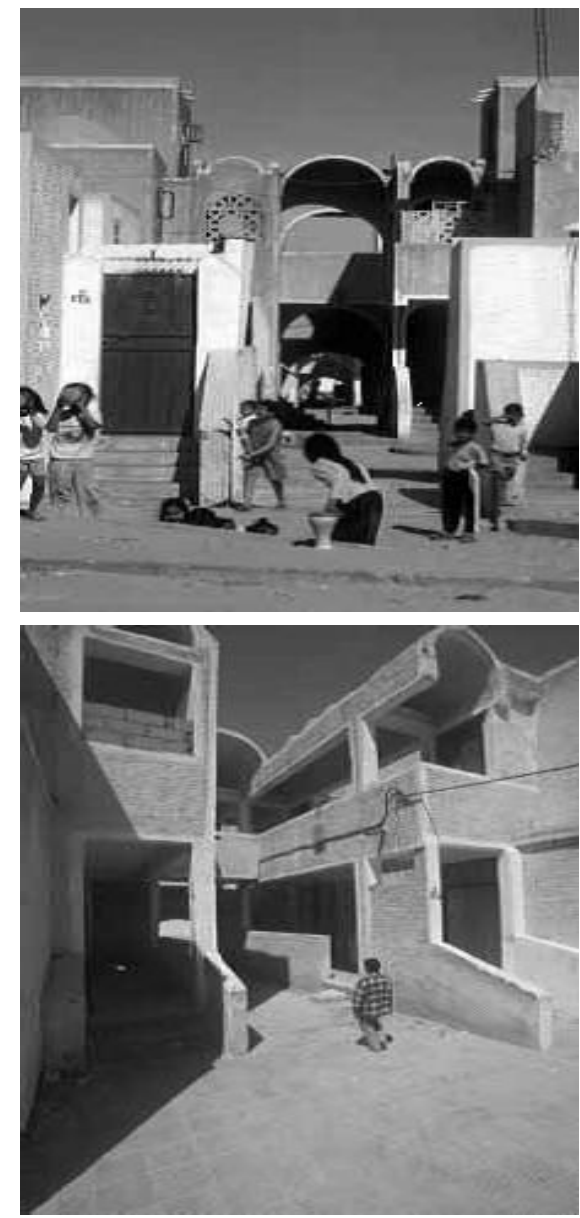

Figure 6. The design concept attempted to develop social fabric of public space including patios, pedestrian pathways, playgrounds, and spaces for women activities

\section{Achievements}

As an achievement, El Oued's housing scheme deserves special attention for its sensitive revival of design forms and culture sensitivity. The design of the unit goes well beyond the simple reproduction of past environments. Its volumes are judicious sober, and genuine. Its extraordinary harmony with the context as well as its multipurpose use and the ambience of its inner space gives it great distinction. The most visible cultural manifestations are in the buildings. Building like these units will help people understand that the search for roots is a way to gain personal and collective identity for which many communities struggle.

\section{Implications}

As an implication of this example, the modern architect has to exercise his creative genius and his artistic sensitivity in creating without losing touch with the established tradition, preserving the implicit and not overlooking the same spiritual and social virtues or the cultural values as in the past ${ }^{9}$. The case also showed that architecture is the most important element of culture and that culture may be defined in terms of the interaction between the intelligence of man and his environment and the satisfaction of both his spiritual and physical needs.

\section{Case study 3: Housing scheme at Ouled Djellal}

The project at Ouled Djellal by El Miniawy architects constituted an attempt at building 200 urban units entirely out of local materials. The units were conceived as a transition between rural housing in the process of urbanisation and urban housing. The height of the buildings was limited to two levels, partly so that it would be well integrated into the existing environment and partly so as not to shock its future inhabitants, who would not be used to living in high rise structures (Figure 7).

Each unit is arranged around a court which provides access both to the reception area and to the family quarter, and also serves a space for domestic activities. The courtyard is an integral part of the design, providing the desired ventilation. The design of the dwelling units was given a flexibility to allow adaptation to the varied and changing population. The spatial organisation of the layout allows rapport with neighbours and integrates public and semi-public spaces.

\section{Method of Approach}

The project is made using only local materials using gypsum stone for the load bearing structure. The architecture is an expression of a local tradition executed in local materials and it represents a cultural continuity in the indigenous way of life. It is considered as a viable solution to the housing problem that fulfils the requirements of contemporary socio-economic realities. The organisation of the layout is dictated by socio-cultural considerations.

The architectural design is developed along three levels of analysis which are:

a. the functional organisation of the dwelling

b. the orientation of the dwelling (for purpose of exposure to sandstorms)

c. the creation of the maximum amount of shade. 
The design is then modified to accommodate those findings. All forms of mechanised ventilation were out of question. Instead, double ceiling for insulation (roofs of domes and vaults), experimenting with wind catchers, various systems of air circulation and cross ventilation through the placement of windows were used.

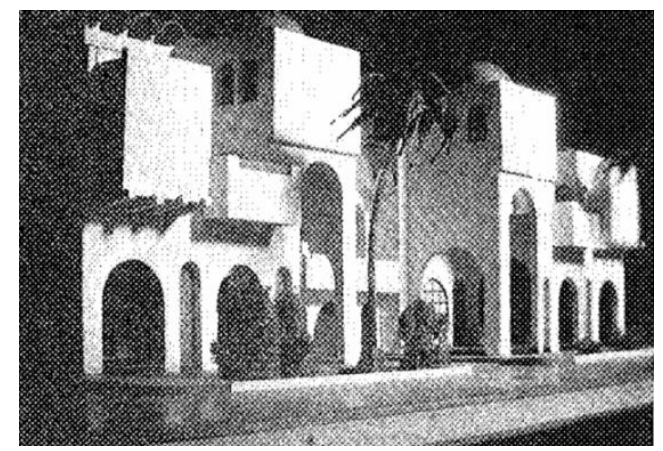

Figure 7. The units were conceived as a transition between rural housing in the process of urbanisation and urban housing

\section{Achievements}

The design provides a model that would satisfy the requirements of local solutions and local construction activity and to favour systems of constructions that are adaptable and easy to use. The project in Ouled Djellal is an attempt in establishing some specific architectural design criteria that would fit in with contemporary Algerian reality, producing an architecture capable of reflecting that reality, and representing a viable alternate to the foreign models that are being introduced all over the world. The design tries to achieve not only the satisfaction of the fundamental needs of families but also to curb the influence of Western models. It is not limited to the definition of kinds and forms of housing but also considers building techniques, local materials in its attempt to satisfy the requirement involved in providing suitable housing.

\section{Implications}

The Ouled Djellal project reflects surely the search for innovation. It is a contribution to the development of architecture relevant to Algeria. As implication the project attempts at using local techniques and materials and consequently eliminates the web of problems involved in relying on imported materials that always accompanies the invasion of Western architectural models.

\section{Conclusion}

This is, by no means, a comprehensive view of contemporary architecture in Algeria, since there are numerous other projects worthy of analysis. Also this paper did not aim at analyzing the full architectural spectrum of the country, but rather to examine through selected examples some of its current architectural trends. It attempts to document examples of architects who are using and reinterpreting indigenous images and motifs and then apply them to contemporary building types.

The earlier example should be seen as part of a continuing tradition, choosing locally available materials and methods of construction and thereby blending superbly with their surroundings and also echoes how to accommodate local traditions with modern technology and hence produce an environment that the community can identify with. The group of cases studies developed in this paper praises the creative and generative process, in which the imagination of the architects, the skills of local artisans and craftsmen, the needs of individuals and communities, and the implicit survival of the environment must interact. John Warren puts it as follow:

"Islam is manifested in a way of life. If that life is reflected in the way the architecture is used, it is sympathetic to that way of life. There, it will become authentic. But I cannot make it Islamic by sticking things on it". ${ }^{10}$

We have to clarify what is Algerian architecture and built environment? I think it is not a style but a way of life imposed by a certain faith, and this has been reflected in architecture and the built environment. The built environment reflects the ideals of an age and the character of the people can be analysed through their built environment and architecture as much as that of an individual through his hand writing. It is obvious that modern problems need modern solutions. Asserting a cultural identity is difficult anywhere, but particularly in Algeria where the lure of high technology has diluted traditional environmental equilibrium. As long as there remains a close relationship between architecture and the community it serves, one can predict the future architecture and built environment will be able to find appropriate answers to modernity.

Post traditional environment is not a fashion but an extension of what is constant in nature, the spirit of the people, the place, and the sun. In order to preserve this varied and rich Arabic traditional environments two paths seem to be followed; shall we go towards an approach which will be more recognisable in the sense some features may be 
applied to the design of buildings-simple images people can associate with. Or shall we take the other approach where the design must be done according to the conditions of the climate, the views, in other words pursue the conventional procedures in architectural design and the list of examples here is very long. In the era of global civilisation the country cannot ignore modern technology, but it has to rationalise it, readapt it and to make it the tool of the culture. That means technology is in the service of the culture and not the other way around. People are more aware now and more concerned with their heritage and with their culture.

\section{References}

$1 \quad$ M. Arkoun. 1983. "Islam et dévelopement dans les pays du Maghreb”. In Arabica. Vol. 9, Part II. p. 114

2 JA. Akbar. 1992. The built environment in Islam. Djeddah, KSA: Islamic Cultural Kibla Dar

3 JJ. Deluze in Pierre Mardaga (ed.). 1988. L'Urbanisme et l'Architecture d'Alger. Alger: OPU. p. 9
4 Renata Holod \& Darl Rastorfer (eds). 1983. Architecture and Community. New York: Aperture. p. 12

$5 \quad$ Udo Kultermann. 1983. “Contemporary Arab Architecture: Architects of Algeria, Tunisia, and Libya”. In Hasan Uddin Khan (ed.). MIMAR 9: Architecture in Development. Singapore: Concept Media Ltd. p. 6

6 Jean Dethier. 1985. Back to the Earth Approach to Housing. Paris: UNESCO Courrier. p. 32

7 Tahar Bellal. 1987. Unpublished Master thesis (M.Phil Architecture): The Potential of Stabilised Soil for Housing in Algeria. England: Newcastle/Tyne University

8 Construire. 1985. Instruction Ministérielle $n^{\circ}$ 05/02/85. Construire Review $\mathrm{N}^{\circ} 2$. Algiers: CNAT. p. 7

9 Sherban Cantacuzino in Renata Holod \& Darl Rastorfer (eds). 1983. Architecture and community. New York: Aperture. p. 32

10 J. Warren. 1982. "Integrating Traditional Areas into the Modern Urban Fabric in Adaptive Reuse". Proceeding of Seminar 3, Designing in Islamic Cultures. Cambridge. p. 42 